\title{
KAJIAN EKSEGETIKAL MAKNA IMAN \\ BERDASARKAN SURAT IBRANI 11:1-3
}

Waharman

waharman@sttab.ac.id

Abstract: $\quad$ The Hebrews were written to strengthen their faith in Christ by carefully explaining the superiority and firmness of God's revelation and redemption in Jesus Christ. He showed that the provision of redemption under the old covenant had been fulfilled and was no longer used because Jesus had come and established a new covenant by His death-working peace. The author also calls on all believers to maintain recognition of Christ so that at the end, the author then advises him to move forward toward spiritual maturity, and to not return to life under penalty by renouncing trust in Jesus Christ. In this study of Hebrews 11: 1-3, the writer provides understanding and understanding, as well as giving advice that faith is the basis for every believer, as well as a certain hope for Jesus Christ. As a result of the church's lack of understanding of the meaning of faith, many apostate congregations who abandoned their faith, beliefs, and perseverance before God disappeared. besides that most of the congregation have experienced the decline of faith. Therefore believers need to understand the text of God's Word from Hebrews 11: 1-3 in every step of life.

Keywords: Exegetical study, faith.

Abstraksi: $\quad$ Surat Ibrani dituliskan untuk memperkuat iman mereka kepada Kristus dengan menjelaskan secara teliti keunggulan dan ketegasan penyataan Allah dan penebusan di dalam Yesus Kristus. Ia menunjukkan bahwa penyediaan penebusan dibawah perjanjian yang lama sudah digenapi dan tidak terpakai lagi karena Yesus telah datang dan menetapkan suatu perjanjian yang baru oleh kematia-Nya yang mengerjakan pendamaian. Penulis juga tetap menghimbau kepada seluruh orang-orang percaya untuk tetap mempertahankan pengakuan terhadap Kristus sehingga pada kesudahannya, selanjutnya penulis memberi nasehat agar terus maju menuju kedewasaan rohani, dan untuk tetap tidak kembali kepada kehidupan di bawah hukuman dengan cara meninggalkan kepercayaan kepada Yesus Kristus. Dalam kajian Ibrani 11:1-3 ini, penulis memberikan pemahaman dan pengertian, sekaligus memberi nasehat bahwa iman adalah dasar bagi setiap orang percaya, sekaligus pengharapan yang pasti kepada Yesus Kristus. Dampak dari ketidak pehaman jemaat tentang makna iman ini, banyak sebagian jemaat yang murtad yang meninggalkan imannya, kepercayaannya, dan ketekunannya dihadapan Tuhan menghilang. selain itu sebagian besar jemaat telah mengalami kemorosotan iman. Maka dari itu orang percaya perlu memahami teks Firman Tuhan dari Ibrani 11:1-3 dalam setiap langkah hidup.

Kata Kunci: Kajian eksegetikal, iman. 


\section{LATAR BELAKANG}

Penulis kitab Ibrani memikili keyakinan yang teguh dan kuat kepada Allah. menurut Drane: Iman Paulus adalah pengalamannya sewaktu bertemu dengan Kristus yang bangkit di jalan menuju Damsyik, peristiwa itu telah mengubah seluruh hidupnya (Kis. 9:1-19; 22:6-16; 22:12-18). Artinya Paulus telah memberikan dirinya dengan sepenuh hati untuk melayani." Dalam Surat Ibrani 11:2-3 inilah suatu gambaran iman dalam setiap kehidupan orang percaya. "Sebab oleh imanlah telah diberikan kesaksian kepada nenek moyang kita. Karena iman kita mengerti, bahwa alam semesta telah dijadikan oleh firman Allah, sehingga apa yang kita lihat telah terjadi dari apa yang tidak dapat kita lihat." Dalam arti iman adalah kepercayaan terhadap karya Allah yang telah dinyatakan di bumi maupun dalam kerajaan sorga. Brill menulis dalam bukunya bahwa:

Iman adalah keyakinan tentang hal-hal yang diharapkan, dan keyakinan tentang hal-hal yang tidak kelihatan. Perkataan Ibrani yang diterjemahkan iman berarti menyokong atau meneguhkan. Iman mempunyai unsur Ilahi dan kemanusiaan. Iman adalah karunia Allah dan juga gerakan manusia. Dasar iman adalah Firman Allah, Rom. 4:20-21. Tujuan iman ialah oknum Yesus Kristus. Iman yang menyalamatkan ialah iman akan Yesus Kristus sebagai juruselamat. ${ }^{2}$

Berdasarkan pendapat di atas memaparkan bahwa iman ialah keyakinan dan keteguhan hati kepada Tuhan di sertai dengan menghidupi Firman-Nya, dan keselamatan yang sudah Allah kerjakan untuk umat manusia melalui Anak-Nya yaitu Yesus Kristus. Oleh sebab itu sifat iman yang sejati ialah percaya terhadap perbuatan Allah sekalipun tidak melihat. Sehubungan dengan itu Iman juga bukan hanya percaya kepada hal yang tidak dikenal, akan tetapi iman dapat mengetahui dan melihat secara langsung karya Allah dan perbuatan-perbuatan Allah yang sungguh luar biasa. Anthony menyatakan dalam bukunya bahwa Iman adalah bukti dan jaminan yang paling kokoh bahwa segala sesuatu yang tidak kita lihat merupakan kenyataan (pragmata). ${ }^{3}$ Halversion menulis dalam bukunya bahwa:

Iman adalah kemampuan untuk berpengang teguh kepada anugerah yang cukup untuk semua hal sedemikian rupa, sehingga apa yang secara manusiawi mustahil menjadi mungkin secara Ilahi. Dengan Allah semua hal adalah mungkin, sehingga kata "mustahil" tidak mempunyai tempat dalam kamus orang Kristen dan gereja Kristus. ${ }^{4}$

\footnotetext{
${ }^{1}$ John Drane, Memahami Perjanjian Baru, (Jakarta: Gunung Mulia,2011). 407

2 J. Wesley Brill, Dasar Yang Teguh, (Bandung: Kantor Kalam Hidup, 1991). 220

3 Anthony A. Hoekema, Alkitab dan Akhir Zaman, (Surabaya: Momentum Christian Literature, 2004). 171

${ }^{4}$ Richard Halversion, Pola Hidup Kristen,(Malang: Gandum Mas, 1989). 266
} 
Jadi, artinya bahwa setiap orang yang sudah percaya dan sudah berpegang teguh akan Firman Tuhan menyakini bahwa segala pengharapan dalam hal apapun akan diberikan kepada setiap orang percaya seperti Firman Tuhan katakan dalam kitab Matius 21:22 "Dan apa saja yang kamu minta dalam doa dengan penuh kepercayaan, kamu akan menerimanya." Tong menulis dalam bukunya:

Jika orang mengatakan "coba buktikan Allah" bagaimana Allah bisa dibuktikan? Jika Allah bisa dibuktikan, berarti bukti itu bisa melingkupi Allah, maka Allah akan menjadi lebih kecil dari bukti, dan bukti menjadi lebih besar dan lebih tinggi kedudukanya dari Allah. ${ }^{5}$

Berdasarkan pendapat diatas penulis menjelaskan bahwa setiap orang percaya sudah benar-benar yakin bahwa adanya Tuhan, dan tidak perlu meminta bukti iman, sebab jika setiap orang Kristen meminta bukti sama halnya tidak yakin akan adanya Allah. Oleh sebab itu iman adalah pengharapan dan keyakinan yang kokoh kepada Dia, sekalipun tidak dapat melihat dan menyetuh-Nya akan tetapi tetap memiliki keyakinan dalam hati bahwa Tuhan ada. . ${ }^{6}$ Bolan menulis dalam bukunya bahwa

Iman itu benar-benar supranatural. Iman hanya berasal dari Allah. Jika iman dipisahkan dari Yesus Kristus, iman tidak bernilai. Iman tidak dapat dibangkitkan dengan pikiran alami atau dipompa sebagai sebuah ban. Iman yang sejati berasal dari suatu hubungan yang intim dengan pencipta iman(Ibr. 12:2). ${ }^{7}$

Pengertian Iman di Perjanjian Baru, Iman berarti: mengamini dengan segenap kepribadian dan cara hidupnya kepada janji Allah, bahwa Ia didalam Kristus telah mendamaikan orang berdosa dengan diri-Nya sendiri, dengan segenap hidup orang yang beriman dikuasai oleh keyakinan. ${ }^{8}$ Dengan janji penebusan yang telah di genapi melalui datangnya Tuhan Yesus diatas kayu salib dan hidup orang percaya harus dikuasai dengan keyakinan yang teguh kepada Tuhan Yesus.

Sujoko mengatakan bahwa "Iman adalah hasil kerjasama Allah dan manusia. Allah memberikan wahyu-Nya dan Ia memampuhkan manusia menangkap wahyu itu. Bahkan, Allah ikut serta dengan manusia dalam penangkapan itu. Dalam iman, itu sudah di kuatkan partisipasi manusia pada kehidupan Allah". 9 Sugiri menulis dalam bukunya bahwa:

Alkitab mengajarkan bahwa Iman itu bersifat eksistensial, mempengaruhi seluruh eksistensi (hidup). Iman adalah pertama-tama 
sesuatu yang lahir dalam hati dan dari sana mempengaruhi seluruh hidup, termasuk akal budi. Ini telah diutaran Paulus di Efesus 3:16, 17. "Aku berdoa supaya Ia, menurut kekayaan kemuliaan-Nya, menguatkan dan meneguhkan kami oleh RohNya didalam hati mu, sehingga oleh iman mu Kristus diam didalam hati mu dan kamu berakar serta berdasar dalam kasih. $^{10}$

Warren mengungkapkan bahwa: "iman yang benar adalah ketaatan yang penuh keyakinan kepada Firman Allah bagaimana pun keadaan dan apapun akibatnya." ${ }^{11}$ Penulis menyimpulkan bahwa beriman adalah mempercayai Firman-Nya, dan kemudian melaksanakan Firman itu tidak peduli bagaimanapun keadaannya atau apapun akibatnya, sekalipun menakutkan namun tetap menaati perintah Tuhan dan percaya bahwa Ia akan melakukan apa yang benar dan apa yang baik. Apabila Tidak menghargai anugerah Tuhan membuat setiap orang menjauh dari rasa syukur kepadaNya akhirnya iman tidak mengalami perkembangan dan tidak berbuah dalam kehidupan. Kehidupan pun menjadi batu sandungan kepada sesama, baik kepada tim pelayanan maupun dalam keluarga. Semua yang di kerjakan tidak membawa damai serta hasil yang memuaskan, tanpa iman semuanya yang di kerjakan akan mengalami kesia-siaan. Brill dalam bukunya mengatakan bahwa:

"Iman adalah karunia Allah dan juga gerakan manusia. Dasar iman adalah iman ialah Firman Allah, Rom. 4:20-21. Tujuan iman ialah oknum Yesus Kristus. Iman yang menyalamatkan ialah iman akan Yesus Kristus sebagai juruselamat." 12

Jadi penulis memamparkan bahwa iman adalah keyakinan dan keteguhan hati orang percaya kepada Firman Allah yaitu kepada Yesus Kristus, mengakui bahwa Yesuslah Juruselamat umat manusia. Wesley mengutip lagi dalam bukunya bahwa iman adalah bukti hak milik segala sesuatu yang diharapkan, dan bukti dari segala sesuatu yang tidak terlihat. Selain itu juga iman adalah dampak dari segala sesuatu yang tidak kita lihat yaitu Firman Allahlah yang menjadi dasar orang percaya. ${ }^{13}$ Salah seorang penulis buku yang bernama Wommack mengatakan bahwa iman manusia adalah didasarkan pada pengetahuan alamiah saja. Tuhan menciptakan umat manusia sebagai makhluk iman. Bahkan sebelum dilahirkan kembali dan terpisah dari pengaruh Tuhan, masih ada iman yang alamiah. Dalam usaha untuk menjelaskan iman, inilah yang diajarkan gereja saya

\footnotetext{
${ }^{10}$ L. Sugiri SJ, Gerakan Kharismatik apakah itu? ( Jakarta: Gunung Mulia, 2006). 242

${ }^{11}$ Ibid,...5

12 J. Wesley Brill, Dasar Yang Teguh, (Bandung: Kantor Kalam Hidup, 1991). 220

${ }^{13}$ J. Wesley Brill, Tafsiran Surat Ibrani, (Bandung: Kalam Hidup, 2004). 176
} 
ketika sedang bertumbuh dalam iman. Iman manusia dibatasi pada apa yang dapat dilihat, dikecap, didengar, dicium, dan dirasakannya. ${ }^{14}$

Dari penjelasan diatas iman berbicara bukan hanya percaya dan mendengar akan tetapi melakukan Firman Tuhan. Iman bukanlah hanya pengakuan dosa, melainkan pengakuan iman: pengakuan yang mempersatukan umat Kristen ke dalam satu persekutuan, seperti pengakuan iman yang berkembang dalam gereja di kemudian hari. Pengakuan iman tersebut memuat unsur-unsur inti iman mereka. ${ }^{15}$ Dari paparan tersebut menunjukkan adanya keragaman dalam pemahaman tentang iman, namun ditengah keragaman tersebut orang percaya harus melihat bagian penting dalam Surat Ibrani yang membahas tentang iman.

\section{METODE PENELITIAN DESKRIPTIF ANALISIS}

Dalam penelitian ini, penulis akan menggali theologia praktikan tentang makna Iman menurut Ibrani 11:1-3. Metode analisis ini adalah suatu proses penelitian untuk menyelidiki suatu peristiwa dan untuk mengetahui keadaan yang sebenarnya serta memberikan gambaran sesuai dengan data yang ada. Penulis juga akan menganalisa tulisan para theolog dalam mencermati tulisan Rasul Paulus khususnya tentang makna iman dan membuat kajian eksegetikalnya. Metode analisis adalah suatu proses penelitian untukk menyelidiki suatu peristiwa dan untuk mengetahui keadaan sebenarnya serta memberi gambaran kebenaran sesuai dengan data yang ada.

\section{LATAR BELAKANG SURAT IBRANI}

Dalam latar belakang ini akan memaparkan penulis surat Ibrani, penerima surat Ibrani, tempat dan waktu penulisan surat Ibrani, bentuk dan gaya penulisan, garis-baris besar surat Ibrani, struktur teks surat Ibrani,

\section{Penulis Surat Ibrani}

Surat Ibrani ini diberi nama atau dialamatkan 'kepada orang Ibrani'. Siapa penulisnya pun tidak tertera dalam surat. Hakh mencatat bahwa "Rupanya, para pembaca telah mengenal penulis dengan baik (Ibrani 13:18-19, 22-24)”. Ada nama yang disebut dalam surat ini, yaitu saudara Timotius (Ibrani 13:23). Akan tetapi tidak jelas siapa Timotius yang disebut itu mungkin saja ia adalah Timotius teman sekerja Paulus, tetapi

\footnotetext{
${ }^{14}$ Andrew Wommack, Roh, Jiwa, Tubuh, (Light Publishing, 2010). 82

15 Bambang Subandrijo, Menyikap Pesan-Pesan Perajanjian Baru, (Bnadung: Bina Media Informasi, 2010). 21
} 
tidak ada bukti yang mendukungnya. ${ }^{16}$ Banyak pandangan yang menjabarkan dan berpendapat siapa penulis surat Ibrani ada yang mengatakan bahwa surat Ibrani ini ditulis oleh Paulus. Guthrie mencatat dalam bukunya bahwa;

Di akhir abad pertama, ada beberapa rujukan spesifik kepada surat Ibrani tetapi rujukan ini sekaligus menunjukan tradisi yang beragam. Di Timur, setidaknya sejak era Pantaenus, surat Ibrani oleh Paulus. Clement dari Aleksandria, yang berpendapat bahwa surat ini ditulis Paulus, mendasarkan pendapatnya dari "penatua terberkati," yang umumnya dianggap sebagai pendahuluannya di Aleksandria, Pantaenus. ${ }^{17}$

Orang-orang yang ada di Aleksandria pun dengan penuh keyakinan bahwa yang menuliskan surat Ibrani adalah Paulus. Dengan demikian maka surat Ibrani akhirnya diterima ke dalam kanon baik di wilayah timur dan juga di wilayah barat. Karena sebelunya surat ini sangat di ragukan. Dalan Enskopedi Alkitab Masa Kini juga menjelaskan bahwa "barulah pada masa Jorome dan Agustinus pengkanonan Kitab di tetapkan di barat" ${ }^{\prime 18}$ pertanyaannya yang timbul adalah jikalau bukan Paulus yang menulis, siapakah penulis Kitab Ibrani yang sebenarnya? Hakh mencatat dalam bukunya yang di kutip oleh Montefiore berpendapat "bahwa Apolos, seorang Kristen yang berasal dari Aleksandria, adalah penulis surat Ibrani. Ia mendukung pendapatnya itu dengan mengatakan bahwa Apolos adalah seorang Yahudi". ${ }^{19}$ Siapa penulis Ibrani tetap merupakan masalah terbesar bagi mereka yang mempelajari Kitab ini. Penulis-penulis yang ditunjukkan jumlahnya banyak, demikian pula pandangan yang mendukung setiap pendapat itu. Inilah berbagai nama yang di asumsikan sebagai penulis Kitab Ibrani;

Rasul Paulus, Apolos, Barnabas, Lukas, Akwila dan Priskila, silas, Ariston dan filipus sang diaken semuanya pernah ditunjuk sebagai penulis, lengkap dengan alasan-alasan pendukungnya. Penelitian terhadap tradisi dari gereja mula-mula dan dari Bapa gereja, baik Timur maupun Barat, hanya membuktikan bahwa ada aneka ragam pandangan. ${ }^{20}$

Dalam hal ini penulis menyimpulkan bahwa penulis surat ini belum dapat di tentukan karena John Drane dalam bukunya, mengutip apa yang ditulis oleh Origenes, bapa geraja dari abad ketiga, menulis mengenai surat ini, "hanya Allah yang mengetahui siapa sebenarnya penulis surat ini". ${ }^{21}$

\footnotetext{
${ }^{16}$ Samuel Benyamin Hakh, Perjanjian Baru, (Bandung: Bina Media Infomasi, 2010). 256

${ }^{17}$ Donald Guthrie, Pengatar Perjanjian Baru "Volume 3", (Surabaya: Momentum, 2009).2

${ }^{18}$ Ibid., 412

${ }^{19}$ Samuel Benyamin Hakh, Perjanjian Baru..., 257

${ }^{20}$ SABDA, (Pendahuluan dan Garis Besar Tafsiran wycliffe) <@ 111> [ Buku/ Topik] (145/357)

${ }^{21}$ Jonh Drane, Memahami Perjanjian Baru, (Jakarta: BPK. Gunung Mulia, 2011). 476
} 


\section{Penerima Surat Ibrani}

Sampai sekarang belum ada kepastian yang akhirnya disepakati bersama oleh para teolog mengenai kepada siapa surat Ibrani ini ditujukan. Hakh menuliskan bahwa "surat Ibrani adalah sebuah tulisan yang berisi wejangan kepada sidang pembaca yang dikenalnya". 22 Ada sesuatu harapan dari penulis kitab Ibrani bahwa ia mau bertemu kembali dengan para pembacanya, dengan kepercayaan bahwa para pembaca merupakan para orang Kristen Yahudi yang setia memegang adat-istiadat kebudayaan Yahudi. Motyer dalam tafsiran menjelaskan bahwa "Isinya dengan kuat meneguhkan, bahwa surat itu ditujukan kepada orang Yahudi." 23 Penerima Surat Ibrani memiliki kaitan yang definit dengan penulis. Selain penulis di atas, penulis jelas mengenal mereka secara pribadi dan ia berharap bisa segera mengujungi mereka $(13: 19,23)$. Ia meminta mereka untuk berdoa baginya (13:18) dan menyebutkan pembebasan Timotius sebagai berita yang penting bagi mereka secara pribadi, khususnya karena ia ingin Timotius bisa mengunjungi mereka bersamanya. ${ }^{24}$ Dalam banyak kasus yang terdapat dalam surat Ibrani khususnya masalah siapa penerima Kitab ini masih menjadi suatu perbincangan yang panjang hingga saat ini. Karena berbagai penemuan dan bukti yang belum bisa dijadikan suatu keputusan bersama untuk memutlakkan siapa sesungguhnya penerima Surat Ibrani.

Tetapi penulis menyimpulkan bahwa Kitab Ibrani memang di peruntukkan kepada orang Ibrani atau juga yang disebut sebagai orang Yahudi yang berada di luar Palestina. Demikian juga dalam tulisan yang dicatat oleh Duyverman yang mengatakan bahwa "Alamatnya“kepada orang Ibrani” tertera dalam segala salinan, sampai pada yang tertua sekalipun. Jadi, karangan ini diperuntukan bagi “orang Ibrani”. ${ }^{25}$ Paham atau istilah yang demikian di gunakan untuk mencirikan orang Yahudi yang berbahasa Aram.

\section{Tempat dan Waktu Penulisan Surat Ibrani}

Tidak semudah yang dipikirkan untuk menentukan lokasi dimana letak penulis Surat Ibrani ini. "Menurut Ibrani 13:23-24, menyebutkan Italia memberikan kesan bahwa surat ini ditulis di Roma. Namun penunjukan tempat penulisan ini tentu masih terbuka untuk tempat yang lain. Jadi, tempat penulisannya pun sulit ditentukan”. Tulis $\mathrm{Hakh}^{26}$. Ada juga paham lain yang menuliskan dimana penulisan Surat Ibrani. "banyak pakar menegaskan tujuan Yerusalem atau Palestina, tetapi ini di karenakan sebagian besar

\footnotetext{
${ }^{22}$ Samuel Benyamin Hakh, Perjanjian Baru..., 258

${ }^{23}$ Alec Motyer, Tafsiran Alkitab Masa Kini 3, (Jakarta: Yayasan Bima Kasih, 2003). 726

${ }^{24}$ Donald Guthrie, Pengantar Perjanjian Baru "volume 3" ..., 16

${ }^{25}$ M.E. Duyverman, Pembimbing ke Dalam Perjanjian Baru, (Jakarta: Gunung Mulia, 2011). 168

${ }^{26}$ Samuel Benyamin Hakh, Perjanjian Baru..., 257
} 
mereka yakni Surat Ibrani di tujukan kepada orang Kristen Yahudi yang tergoda untuk kembali kepada Yudaisme". ${ }^{27}$ Kemungkinan besar surat ini ditulis sekitar tahun enam puluhan Masehi. Seandainya pada waktu surat ini ditulis di Yerusalem dan Bait Allah telah jatuh ketangan orang Romawi, pasti penulis akan menyebutkannya karena ia berbicara mengenai para imam dan kurban persembahan. Jadi, hampir dapat di pastikan di tulis sebelum tahun 70 M. Jika surat ini ditunjukan kepada jemaat di Roma (13:24) dan menyinggung soal penganiayaan yang dilakukan Kaisar Nero, berarti surat ini ditulis antara tahun 64 dan $70 \mathrm{M}^{28}$ Surat ini ditulis dalam masa hidup generasi Kristen yang kedua (Ibrani2:1-4) dan pada suatu tenggang waktu yang cukup lama setelah orang-orang itu menjadi percaya dan bertobat (5:12). Surat ini rasanya paling sesuai dengan keadaan pada akhir dekade keenam, ketika gereja di Roma Tengah ketakutan menghadapi penganiayaan dan kejatuhan persemakmuran Yahudi sesudah di ambang pintu. Tulis Tenney. $^{29}$

Jadi, penulis menyimpulkan bahwa apa yang dicatat oleh para teolog mengenai tempat dan waktu merupakan tafsiran yang berdasarkan pada bukti-bukti yang telah ditemukan. Tentu apabila ada perbedaan antara yang satu dengan yang lain merupakan hal yang lumrah, disebabkan perbedaan latar belakang para teolog.

\section{Bentuk dan Gaya Penulisan}

Surat Ibrani memiliki penutup tanpa salam penutup dan alamat, sehingga bentuk suratnya dipermasalahkan. Bagian penutup dan runjukan pribadi dan kepada pembaca menunjukkan bahwa surat Ibrani adalah sebuah surat, tetapi gaya, metode argumentasi, dan beberapa indikasi kecil (seperti "aku akan kekurangan waktu apabila aku hendak menceritakan," 11:32) menyerupai sebuah khotbah. ${ }^{30}$ Searah dengan hal ini, Deissmen melihat "surat Ibrani sebagai contoh pertama literatur seni Kristen." 31 Tetapi hal ini jangan terlalu di tekankan karena surat Ibrani jelas di rancang untuk menjawab kebutuhan situasi histori tertentu, dan tidak tampak seperti "praktik sasra belaka." Situasi historis juga melenyapkan kemungkinan bahwa surat Ibrani awalnya di maksudkan sebagai surat edaran. Beberapa pakar fokus pada struktur surat mengklaim telah menemukan penyatuan

\footnotetext{
${ }^{27}$ Donald Guthrie, pengantar Perjanjian Baru "volume 3" ..., 27

${ }^{28}$ Yep wei Fong, Hanbook to the Bible "Pedoman Lengkap Pendalaman Alkitab".(Bandung: Kalam Hidup, 2015). 707

${ }^{29}$ Merrill C. Tenney, Survei Perjanjian Baru (Malang: Gandum Mas, 1997). 444

${ }^{30}$ Donald Guthrie, pengantar Perjanjian Baru "volume 3"..., 42

${ }^{31}$ A. Deissmenn, the new Testament in the Light of Modern Research, (1929). 51
} 
dua atau lebih bagian. ${ }^{32}$ Pakar lain mendukung bahwa struktur surat Ibrani sengaja dirancang seperti ini, karena mereka melihat simetris kosentris di dalamnya. ${ }^{33}$

\section{Latar Belakang Teks Surat Ibrani 11:13}

Kata pengantar ini menyatakan tiga hal mengenai iman: Ayat 1 berkata bahwa iman pada hakekatnya adalah kenyataan dan kepastian dari apa yang belum kita alami, ayat 2 berkata bahwa iman membawa kehormatan istimewa bagi tokoh-tokoh sejarah Israel, dan ayat 3 berkata bahwa iman merupakan suatu pandangan hidup yang khusus, yang mempengaruhi setiap pikiran dan kegiatan kita di dalam dunia ini, karena dengan iman kita menyadari bahwa dunia ini didahului dengan "apa yang tidak dapat di lihat."

Rasul Paulus mendefinisikan iman sebagai 'dasar dari segala sesuatu yang di harapkan dan bukti dari segala sesuatu yang tidak terlihat' (Ibrani 11:1). Alma memaklumkan bahwa iman bukanlah suatu pengetahuan yang sempurna; alih-alih, jika beriman, 'berharap untuk segala sesuatu yang tidak terlihat, tetapi adalah benar. Selain itu, belajar dalam Lectures on Faith bahwa iman adalah 'asas utama dalam agama yang diungkapkan, dan landasan dari segala kesalehan' dan bahwa itu juga adalah 'asas dari tindakan dalam diri semua makhluk cerdas.'

Ajaran-ajaran ini menyoroti tiga unsur dasar dari iman: (1) iman sebagai keyakinan dari apa yang diharapkan yang adalah benar, (2) iman sebagai bukti dari apa yang tidak terlihat, dan (3) iman sebagai asas dari tindakan dalam semua makhluk cerdas. Saya menggambarkan tiga komponen iman kepada Juruselamat ini sebagai secara bersamaan menghadap masa depan, melihat ke masa lalu, dan memprakarsai tindakan di masa kini. Iman sebagai keyakinan akan apa yang diharapkan menatap ke masa depan

Iman kepada Kristus secara tidak terelakkan terikat pada, dan berakibat pada, harapan kepada Kristus untuk penebusan dan permuliaan. Dan keyakinan serta harapan berjalan ke tepi cahaya dan berjalan beberapa langkah ke dalam kegelapan mengharapkan dan memercayai terang tersebut bergerak dan menerangi jalan. Kombinasi dari keyakinan dan harapan memprakarsai tindakan di masa kini. "Iman sebagai bukti akan apa yang tidak terlihat menatap masa lalu dan mengukuhkan kepercayaan kepada Allah dan kepercayaan pada kebenaran dari apa yang tidak terlihat. Melangkah kedalam kegelapan dengan keyakinan dan harapan, serta menerima bukti dan pengukuhan sewaktu terang kenyataannya bergerak dan menyediakan penerangan yang butuhkan. Kesaksian yang di

\footnotetext{
${ }^{32}$ Donald Guthrie, pengantar Perjanjian Baru "volume 3" ..., 42

33 A. Vanhoye, La Structure Litteraire de I'Empire aux Hebreux, (1976). Bdk. Juga J. Swetnam, "From and Content in Hebrews 7-13," Biblica 55 (1974). hal. 333-348.
} 
dapatkan setelah pencobaan iman (lihat Ester 12:6) adalah bukti yang memperbesar dan memperkuat keyakinan. Keyakinan, tindakan, dan bukti saling memengaruhi dalam proses yang berkelanjutan". 34

\section{KAJIAN ESEGETIKAL SURAT IBRANI 11:1-3 TENTANG MAKNA IMAN}

Dalam kajian ini akan mengeksegese beberapa kata yang penting untuk mendapatkan kajian yang mendalam sehingga dapat memahami makna iman sejati menurut Ibrani 11:1-3. Pemaparan ini akan memudahkan pembaca untuk mengerti dan pemaparan yang di jelaskan melalui perbandingan versi, struktur teks, dan latar belakang teks.

\section{Iman adalah Dasar Bagi Orang Percaya}

Berbicara tentang iman, ialah suatu kepercayaan, terutama kepada reabilitas Allah. Sedang dalam pengertian zaman modern iman adalah semacam pengetahun yag lebih rendah atau penerimaan pendapat atau berita, yang tidak sepenuhnya dapat di buktikan. Makna Alkitabiah iman (kata yang berkaitan denganya adalah kepercayaan) lebih terletak pada hakikat komitmen, meskipun dalam kenyataan tersirat juga adanya dasar yang membuat iman tak dapat didukung dengan bukti historis secara meyakinkan. ${ }^{35}$

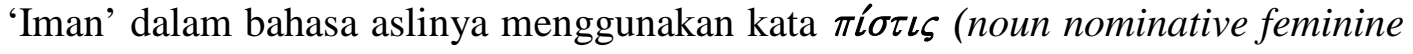
singular common) menujukkan kata benda dalam bentuk kata ganti orang ke-1 feminim umum. Ini suatu kata benda satu kali terjadi sampai seterusnya. Artinya iman, kepercayaan, dan komitmen setiap orang yang percaya, dan tidak dapat digugah. Jadi iman adalah suatu komitmen setiap orang yang percaya akan Tuhan. Dalam pandangan friberg mengataka as a decision to be faithful and loyal to the Christian religion promise, pledge, commitment as a conviction that brings certainty faith, assurance as a Christian virtue, especially along with hope and love characterizing believers yang artinya sebagai keputusan untuk setia dan setia kepada agama Kristen dan suatu janji atau komitmen sebagai hukuman yang membawa iman kepastian, jaminan sebagai kebaikan Kristen yang terutama bersama dengan berharap dan cinta yang menandai yang percaya. ${ }^{36}$

dalam perbandingan versi NKJV mengatakan Now faith is the substance sekarang iman adalah unsur suatu harapan. Sedangkan dalam BIS mengatakan Beriman berarti

\footnotetext{
${ }^{34}$ Seek Learning by Faith, ( Ensign, September 2007). 61-63

${ }^{35}$ W.R.F Browning, Kamus Alkitab, (Jakarta: Gunung Mulia, 2011). 150

${ }^{36}$ Friberg, Analytical Greed exicon, Bibleworks 21981
} 
yakin sungguh-sungguh akan hal-hal yang diharapkan, dan dalam FAYH mengatakan apakah iman itu? Iman ialah keyakinan bahwa apa yang kita inginkan akan terlaksana. Jadi arti iman adalah suatu unsur harapan setiap orang percaya dan keyakinan, kesungguhsungguhan.

Herlianto dalam bukunya menjelaskan bahwa iman adalah "positive Confession" yang dipopulerkan oleh Kenneth Hagin, yang dimaksudkan disini adalah bahwa kata-kata pengakuan yang kita ucapkan mempunyai kuasa kreatif. Artinya apa yang kita ucapkan akan menentukan apa yang akan kita alami. Setiap pengakuan (Confession) yang kita harapkan/inginkan harus diucapkan secara positip dan tanpa sikap ragu-ragu, maka dipercaya Tuhan akan mengabulkannya. ${ }^{37}$ Hagin menegaskan bahwa: "kamu akan memperoleh apa yang kamu ucapkan. Kamu dapat menulis tiketmu sendiri dengan Tuhan. Dan langkah pertama menulis tiketmu sendiri dengan Tuhan adalah 'katakan' ${ }^{38}$

Penulis mengambil satu kesimpulan terhadap pandangan diatas bahwa iman bukan sekedar percaya dan berkata-kata tetapi harus memiliki suatu kuasa dalam arti keyakinan yang kokoh dan tanpa ada keraguan sedikitpun, dalam arti tetap dalam pendirian. Dalam hal ini Hagin memberi penjelasan bahwa setiap orang berkata dan mengakui Dia adalah Tuhan dan Juruselamat maka itu merupakan tindakan yang pasti memberi jaminan hidup bagi kita untuk melangkah lebih baik lagi. Sedangkan dalam KBBI iman adalah keyakinan, kepercayaan, ketetapan hati, dan keteguhan batin. ${ }^{39}$ selanjutnya Janette Oke menegaskan dalam bukunya bahwa iman adalah percaya dengan sengenap orang bahwa Allah mengasihi setiap orang yang percaya, memelihara, dan memperhatikan segala kebutuhan orang-orang yang percaya kepada-Nya. Oleh sebab itu iman yang besar kepada Allah berarti kerendahan hati, ketaatan dan pertumbuhan. Hasilnya belum tentu berupa keberhasilan, kesehatan, yang baik, ketenaran, prestasi ataupun berkat keuangan; hasilnya yang paling nyata adalah buah Roh (Galatia 5:22,23). Jadi iman jangan sekali-kali diukur dengan apa yang dimilki meliankan dengan keadaan setiap orang percaya. ${ }^{40}$ jadi, penulis menyimpulkan bahwa iman merupakan suatu keyakinan, keteguhan batin, serta ketetapan hati seseorang untuk mengambil suatu tindakan atau komitmen dalam hidupnya, sehingga dalam keyakinan tersebut membentuk suatu ketaatan dan kesetiaan kepada Tuhan.

\footnotetext{
${ }^{37}$ Herlianto, Toronton Blessing, (Bandung: YABINA, 1996). 68

${ }^{38}$ Kenneth Hagin, How to Write Your Own Ticket With God, (Faith Library, Tulsa,1979). 8

39 Dendy Sugono, Kamus Besar Bahasa Indonesia Pusat Bahasa, (Jakarta: Gramedia Pustaka Utama, 2011). 1492

${ }^{40}$ Janette Oke, Pola Hidup Kristen, (Malang: Gandum MAS,1989). 285
} 
Kata 'Now faith' yang artinya 'sekarang iman'41 kata 'sekarang' ini menunjukan suatu keyakinan dan suatu penekanan bahwa iman adalah suatu harapan keyakinan dan kenyataan dalam diri sesorang. Prime menjelaskan bahwa iman adalah suatu tindakan yang menentukan dan sikap yang terus-menerus. Iman mulai sebagai tindakan seseorang yang membuang kepercayaan pada diri sendiri untuk mendapat keselamatan. ${ }^{42}$ Holmes menegaskan dalam bukunya iman adalah respon manusia kepada penyataan diri Allah. Ini tindakan manusia yang muncul dari pekerjaan Allah. ${ }^{43}$

Iman adalah "dasar" dari segala sesuatu yang kita harapkan dan bukti dari segala sesuatu yang tidak kita lihat. Kata "dasar" dalam bahasa Yunani yaitu urootougs (hupostasis) noun nominative feminine singular common from, menujukkan kata benda dalam bentuk kata ganti orang ke-1 feminim umum. Ini suatu kata benda satu kali terjadi sampai seterusnya. yang artinya kepercayaan, dan jaminan. Friberg kata dasar ialah Friberg, as the objective reality that gives a firm guarantee and basis for confidence or assurance substance, ground of hope, foundation. Yang artinya kenyataan sasaran yang memberi suatu jaminan perusahaan yang basis untuk kepercayaan atau unsur jamiman atau landasan, harapan/pondasi. ${ }^{44} \mathrm{Jadi}$, penulis menyimpulkan bahwa dasar disini ialah suatu jaminan atau kepercayaan dalam diri seseorang. Sedangkan dalam TL, dasar adalah "percaya yang sungguh-sungguh" dalam NKJV memakai kata "substance” mengandung arti "unsur" dalam arti bahwa dasar adalah suatu unsur yang terdapat dalam diri seseorang untuk mengambil suatu tindakan yang pasti.

Menurut Henry mengakatakan bahwa iman adalah dasar sesuatu yang kita harapkan. Iman dan harapan berjalan bersama-sama. Hal-hal yang sama yang kita harapkan adalah juga hal-hal yang kita imani. Iman adalah keyakinan dan harapan teguh bahwa Allah berkenan menggenapi semua yang telah di janjikan-Nya kepada kita di dalam Kristus. Keyakinan ini begitu kuat sehingga membuat jiwa seakan-akan memiliki hal-hal tersebut dan buah-bauhnya pada saat ini, dan membuat hal-hal itu hidup didalam jiwa, dengan mengecap buah-buah pertama diriNya. Sehingga dalam menjalankan iman orangorang percaya dipenuhi dengan sukacita yang mulia dan yang tidak terkatakan. Menurut Gary Dausey menjelaskan dalam bukunya bahwa dasar adalah suatu bangunan yang

\footnotetext{
${ }^{41}$ Bibleworks, 12 September, 2019 pukul...,8:32 WIB

42 Derek Prime, Tanya Jawab tentang Iman Kristen, (Jakarta: Yayasan Komunikasi Bina Kasih/OMF, 2006). 114

${ }^{43}$ Arthur F. Holmes, Segala Kebenaran adalah Kebenaran Allah, (Surabaya: Momentum Christian Literature, 2009). 122

${ }^{44}$ Friberg, Analytical Greed exicon, Bibleworks, 27626
} 
dibangun dengan fondasi yang lebih akurat dan fondasi yang tidak mudah digoyahkan oleh siapapun. ${ }^{45}$ Dasar artinya keutamakan, atau yang paling terpenting iman tidak bisa menjadi nomor dua dalam hidup seseorang melainkan hal yang paling utama atau pertama dalam setiap kehidupan orang percaya.

\section{Iman adalah Dasar Pengharapan Orang Percaya}

Berbicara tentang pengharapan ini merupakan suatu kesamaan dengan iman dimana iman adalah keyakinan atau kepercayaan. Sedangkan pengharapan juga sama dalam arti memiliki suatu keteguhan hati, keyakinan hati, harapan akan janji Allah. Henry menjelaskan bahwa pengaharpan adalah teguh bahwa Allah akan menggenapi semua yang telah dijanjikan-Nya kepada kita di dalam Kristus. ${ }^{46}$

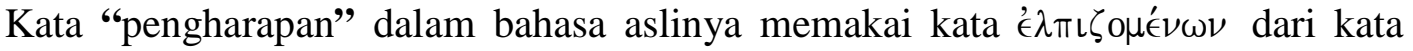
dasar '́ $\lambda \pi i \zeta \omega$ verb participle present passive genitive neuter plural yang menujukkan suatu kata kerja dalam bentuk perintah bersifat tetap yang menandakan suatu kepunyaan dalam bentuk jamak. Yang artinya kesetiaan, kwalitas, komitmen dan ke andalan. Dalam NKJV Memakai kata Hoped for yang artinya yang diharapkan. Sedangkan dalam NET, mengatakan we hope for yang artinya mengharapkan. Dalam KBBI memakai kata berharap yang artinya: keinginan supaya sesuatu terjadi, rindu, dan selalu menanti. Jadi, penulis menyimpulkan bahwa kata pengharapan adalah suatu kualitas yng berpusat dalam satu tujuan yaitu harapan benar-benar terjadi, atau sesuatu yang diharapkan itu pasti diterima. Marty mengatakan dalam bukunya bahwa pengharapan adalah kepercayaan yang menaruh harapan yang patis, adanya kepastian, jaminan. ${ }^{47}$

\section{Iman Adalah "Bukti” Bagi Orang Percaya}

Kata "Bukti" dalam bahasa aslinya memakai kata : "' $\lambda \in \gamma \chi 0 \varsigma$, (elegchos) noun nominative masculine singular common, menunjukkan suatu kata benda dalam bentuk kata ganti .oranng ke-1 (tunggal) dalam bentuk maskulin umum. Jadi penulis menyimpulkan bahwa kata bukti: melakukan, bertindak, menyatakan, membuktikan dari dalam hati sampai bertindak dengan dunia nyata. Dalam AV memakai kata: reproof, evidence. artinya teguran, bukti. Sedangkan dalam NKJV memakai kata evidence artinya bukti. Sedangkan dalam BIS lebih menekankan bahwa bukti adalah mempunyai kepastian.

\footnotetext{
${ }^{45}$ Gary Dausey, Pola hidup kristen, (Bandung: Yayasan Klam Hidup, 1989). 257

${ }^{46}$ Matthew Henry, Tafsiran Surat Ibrani, Yakobus, 1\&2 Petrus, 1-3 Yohanes, Yudas, Kitab Wahyu, (Surabaya: Momentum Christian Literatur, 2016). 186

${ }^{47}$ Martin marty, Pola Hidup Kristen, (Surabaya: Yakin, 1989). 290
} 
Penulis meyakini bahwa bukti adalah tindakan dan menyatakan dalam hal bahwa memberi kepastian untuk sungguh-sungguh melakukannya.

Matthew Henry menjelaskan bahwa: iman adalah bukti dari segala sesuatu yang tidak dilihat. Iman menunjukkan kepada akal budi kenyataan dari hal-hal yang tidak dapat dicerna oleh mata jasmani. Iman adalah persetujuan teguh dari jiwa terhadap wahyu ilahi dan setiap bagian darinya, dan mencerahi jiwa bahwa Allah itu benar. Iman adalah persetujuan penuh akan semua hal yang telah diwahyukan Allah sebagai kudus, adil, dan baik. Iman membatu jiwa menerapkan semua itu pada dirinya dengan segala perasaan dan perbuatan yang sesuai. Jadi, iman dirancang untuk melayani orang percaya sebagai alat penglihatan, dan bagi jiwa, iman bertindak layaknya pancaindra bagi tubuh.

\section{Iman adalah Percaya dan Tidak Melihat}

Kata percaya dan tidak melihat dalam bahasa aslinya memakai kata: $\beta \lambda \epsilon \pi o \mu \epsilon \nu \omega \nu$ dari kata dasar $\beta \lambda \epsilon ́ \pi \omega$ (verb participle present passive genitive neuter plural from). ini merupakan kata pertisip kata kerja yang menyajikan sautu kata sifat genetis pasif dalam bentuk jamak. artinya hati-hatilah, jagalah, melihat, disaksikan. Jadi, penulis menyimpulkan bahwa tidak melihat disini menunjuk pada kesaksian dalam arti sekalipun tidak melihat namun tetap percaya akan Tuhan dan mempraktekan dalam kehidupan sehari-hari.

Sedangkan dalam FAYH mengatakan Iman ialah kepastian bahwa yang diharapkan sudah menantikan, walaupun hal itu belum dapat dilihat sekarang. Dalam NKJV memakai kata the evidence of things not seen. Yang artinya bukti macam hal tidak melihat. Dalam BIS mengatakan; berarti mempunyai kepastian akan hal-hal yang tidak dilihat. Jadi, artinya sekalipun tidak melihat namun percaya atas karya Allah dan membuktikan dan memperlihatkan bawah iman adalah harapan yang teguh dalam setiap persoalan hidup. Menurut Henry mengakatakan dalam bukunya bahwa:

Iman mereka adalah kehormatan mereka. Iman mematulkan kehormatan pada diri mereka. Mereka adalah kehormatan bagi iman mereka, dan iman mereka adalah kehormatan bagi mereka. Iman membuat mereka melakukan hal-hal yang memberikan kesaksian baik, dan Allah telah memberi perhatian supaya ada catatan dan kesaksian yang ditulis tentang hal-hal baik yang mereka lakukan dengan kekuatan anugerah ini. Tindakan-tindakan iman yang tulus akan tahan untuk disaksikan, patut disaksikan, dan akan ketika disakiskan, membawah kehormatan mereka yang sungguh-sungguh percaya. Pertama: percaya bahwa alam semesta ini tidak abadi, tidak pula terjadi dengan sendirinya, tetapi dijadikan oleh yang lain; kedua bahwa penciptaan alam semesta adalah Allah. Dialah penciptaan segalanya, dan siapa saja yang menciptakan segalanya seperti 
ini pastilah Allah. Ketiga bahwa Allah menjadikan dunia dengan ketepatan yang tinggi. Dunia adalah pekerjaan yang terbentuk, segala sesuatunya disesuaikan dan dicondongkan untuk memenuhi tujuannya. Ke empat bahwa Allah menciptakan dunia oleh Firman-Nya, yaitu oleh hikmat-Nya yang hakiki dan Anak-Nya yang kekal, dan oleh kehendakNya yang bekerja, yang berkata, terjadilah, maka semuanya jadi (Maz. 33:9). ${ }^{48}$

Percaya berarti pengorbanan. Setelah Abraham lepas dari segala kepastiannya yang dahulu itu, ia harus pula mengorbankan anaknya yang sangat dikasihi-Nya (Kej 22). Percaya berarti bahwa kita diberikan sikap yang baru terhadap apa yang disebut "realitas sehari-hari".sebab "Realitas abadi" telah menguasai hidup. Oleh karena itu orang-orang beriman adalah sebagai orang asing dan pendatang di bumi ini (Ibr 11:13-14). Percaya berarti kebangkitan untuk memulai hidup yang baru. Ur adalah negeri yang terkenal, ditinggalkan oleh Abraham; dirinya yang dahulu itu, telah di serahnya ke dalam kematian (Gal 6:14); lalu lahirlah seoarang manusia baru (Gal 2:20). Abraham percaya kepada Allah yang hidup yakni Allah yang menghidupkan orang mati dan membuat dengan firmaNya apa yang tidak ada menjadi ada (Rm 4:17). Percaya berarti, bahwa bukan aku lagi yang hidup melainkan Kristus, firman Allah yang hidup dalam diriku. Aku hidup dari iman dan oleh iman (Rm 1:17). Iman itu hidupku. Tuhanlah yang menjadi hidupku. Ke percaya berarti kemenangan. kemenangan yang mengalahkan dunia, iman( 1 Yoh 5:7). sungguhpun seluruh tanah itu telah dijanjikan kepadanya (Kej 12:7; 15:7). Tetapi Abraham mempercayainya, biarpun bertentangan dengan segala yang dilihat dan dialaminya. Dengan "mata iman "ia melihat sesuatu yang lain. Percaya Adalah dasar dari segala sesuatu yang tidak terlihat (Ibr 11:1). Percaya di tengah-tengah kegelisahan, artinya, percaya bukanlah "milik" yang terlindung, bukanlah model yang memungkinkan hidup daripada bunganya. Percaya adalah berjuang untuk menjadi percaya. Kehidupan Abraham memperlihatkan kepada kita, bahwa kadang-kadang imannya terancam hilang: Ismael adalah bagaikan anak dari ketidak percayaan Abraham (Kej 16; Gal 4:23). Siapa yang percaya, ia berdoa: Aku percaya. Tolonglah aku dalam ketidak percayaanku (Mrk 9:24). ${ }^{49}$

\section{KAJIAN TEOLOGIS TENTANG MAKNA IMAN}

Iman secara hakiki berkenan dengan dua macam hal, hal-hal dimasa depan (atau yang diharapkan) dan hal-hal yang tidak kelihatan. Iman itu memilki keyakinan yang sama

\footnotetext{
${ }^{48}$ Matthew Henry, Tafsiran Surat Ibrani, Yakobus, 1\&2 Petrus, 1-3 Yohanes, Yudas, Kitab Wahyu, (Surabaya: Momentum Christian Literature, 2016). 189

${ }^{49}$ G.C. Van Niftrik, Dogmatika Masa Kini, (Jakarta: Gunung Mulia, 2015). 44-45
} 
terhadap pemenuhan yang akan datang dari yang satu, serta kenyataannya dimasa kini dari yang kedua. Tanpa sikap yang penuh kesadaran dan kepastian terhadap Allah yang dinyatakan secara aktif demikian, tidak mungkin orang berkenan kepada Allah atau memiliki hubungan pribadi dengan Dia jikalau tidak menghampiri Allah. ${ }^{50}$ Dalam kajian ini memaparkan beberapa makna iman berdasarkan pemikiran teologis.

\section{Penyerahan Diri Secara Total kepada Allah.}

Seorang hamba Tuhan atau pelayan harus betul-betul memberi diri untuk kepentingan pelayanan. Seseorang yang betul-betul mengabdikan dirinya untuk pelayanan, rela kehilangan hak. Tuhan Yesus melepaskan segala hak demi tugas pelayanan yang diberikan kepadaNya. Ia rela melapaskan apa yang menjadi milik-Nya demi kepentingan kerajaan Allah. Hak-hak tersebut antara lain, hak untuk di hormati, dikasihi, di perlakukan adil, menikmati milik sendiri. ${ }^{51}$ Tanpa penyerahan, pelayanan hanya akan menjadikan seorang sebagai sebuah mesin, yang melakukan tugasnya tanpa hati. ${ }^{52}$ Agar setiap orang percaya benar-benar menyerahkan dirinya di dalam kuasa Tuhan, segenap hati. Anda tidak menginginkan sebagian dari hidup Anda. Dia meminta kita segenap hati kita, segenap jiwa kita, segenap akal budi kita, dan dengan segenap kekuatan kita. Allah tertarik pada komitmen separuh hati, ketaatan sebagian, dan sisa-sisa waktu dan mengabdi kepada Allah. ${ }^{53}$ Menurut Eddy dalam bukunya mengatakan bahwa:

Sesungguhnya tak ada seorang pun yang dapat kita percayai, bahkan kepercayaan suami dan istri, orang tua dan anak, sesama saudara sekandungpun dapat berakhir dengan kecurigaan, perselisihan, perpisahan, dendam kusumat atau pembunuhan. Hubungan manusia yang tidak di bangun atas iman percaya yang sejati dalam Yesus Kristus akan terancam kesia-siaan dan kehancuran. Dia juga berjanji akan setia memelihara mereka yang bersandar kepada-Nya. Sebab itu serahkan seluruh kekuatiran mu kepada-Nya (I Petrus 5:7). Hanya mereka yang sungguh-sungguh percaya kepadaNya, yaitu mereka yang berserah penuh kepadaNya akan menikmati kebahagiaan yang sejati. ${ }^{54}$

Terhadap pandangan di atas, penulis setuju bahwa salah satu cara penyerahan diri secara total ialah percaya secara total, dan mengabdi kepada Allah serta penyerahan diri dalam arti bahwa Allah adalah maha pelindung, maha penyayang, maha tahu, dan maha mulia. Jadi iman yang sejati adalah mencakup tentang kemustahilan bagi dunia menjadi

\footnotetext{
${ }^{50}$ A. Simanjuntak, Tafsiran Alkitab Masa Kini 3 Matius-Wahyu, (Jakarta: Yayasan Komunikasi Bina Kasih/OMF, 2003). 761

${ }^{51}$ Erastus Sabdono, Pelayanan Yang Sesungguhnya, (Jakarta: Rehobot Literatur, 2017). 74

${ }^{52}$ Brian J. Bailey, Pilar-Pilar Iman, (Jakarta: Zion Christian Publications, 2005). 56

${ }^{53}$ Paulus Adiwijaya, Rick Warren the Purpose Driven life, (Malang: Gandung Mas, 2004). 11

${ }^{54}$ Eddy Fance, mengenal dan di kenal Allah, (Jakarta: Yayasan Sinar Nusantara, 2005). 47
} 
tidak mustahil bagi Allah, dalam Friman Allah mengatakan: "sesungguhnya sekiranya kamu mempunyai iman sebesar biji sesawi saja kamu dapat berkata kepada gunung ini: pindah dari tempat ini ke sana, maka gunung ini akan pindah, dan takkan ada yang mustahil bagimu." ( Matius 17:20). ${ }^{55}$ Pernando menjelaskan dalam buknya sikap penyerahan diri menurut Alkitab adalah menyerahkannya kepada Kristus dan membiarkan Kristus menjadi Tuhan atas hidupnya. ${ }^{56}$ Kristus tidak membinasakan setiap diri orang percaya yang diserahkan kepada-Nya, malahan Ia menebuskanya dan memberikannya kepada kepada satiap orang yang percaya kepacaya.

\section{Ketaatan Dan Kesetiaan Kepada Allah}

Kata 'setia' dalam bahasa Ibrani, berasal dari sebuah kata 'sokong' atau tanggung' yang artinya Orang yang setia berarti orang yang dapat menyongkong, yang menanggung, yang kepadanya kita dapat bersandar tanpa merasa kuatir (Ul. 7:9;32:4; Yes. 49:7; 1 Kor. 1:9; 10:13, 1 Tes. 5:24, 2 Tes. 3:3, 1 Yoh. 1:9). ${ }^{57}$ Dapat di simpulkan bahwa orang yang setia adalah seorang yang menyadari bahwa Allah setia sehingga ia mau untuk memperhatikan satu sama lain sebagai saudara dalam Tuhan.

Melalui pemaparan di atas Rey juga menjelaskan bahwa kesetiaan dalam bahasa Yunani disebut pistis. Kesetiaan ini juga terdalam dalam Amsal 20:6,”... tetapi, orang yang setia siapakah yang menemukannya" ayat ini memiliki arti, kesetiaan itu langkah ditemukan, karena itu ketika orang percaya memiliki kesetiaan, maka ia akan menjadi teladan bagi dunia yang dahaga akan kesetiaan. ${ }^{58}$ Dapat di simpulkan bahwa tidak semua orang memiliki kesetiaan itu, tetapi ketika orang percaya memiliki kesetiaan di hadapan Tuhan maka dari situlah orang percaya dapat menjadi teladan bagi dunia. Naftrik mengatakan bahwa kesetiaan Allah sang khalik adalah kesetiaan terhadap dunia dan manusia yang berdosa. ${ }^{59}$ Mengapa orang percaya harus memiliki kesetiaan? Dan bahkan kesetiaan orang percaya harus menjadi telada, penulis menyimpulakan bahwa Allah sudah terlebih dahulu setia kepada umatNya. Selanjutnya, seperti yang telah dikatakan oleh Barth bahwa kesetian Tuhan kepda umatNya mengajarakan kepada umat pilihannya agar umat pun setia kepda Allah. ${ }^{60}$ Brake juga mengatakan bahwa kita setia dalam mencari Allah karena kita memandang Allah itu baik dan murah hati. ${ }^{61}$ Caram mempertegas dalam

\footnotetext{
${ }^{55}$ A. Simanjuntak, Tafsiran Alkitab Masa Kini 3 Matius-Wahyu,.. 12

${ }^{56}$ Ajith Fernando, Pola Hidup, (Bandung: Kalam Hidup, 1989). 216

${ }^{57}$ J. Wesley Brill, Dasar Yang Teguh, (Bandung: Kantor Kalam Hidup, 1991). 90

${ }^{58}$ Hendra Rey, Menata Hidup Serupa Kristus, ( Bandung: PT. Visi Anugerah Indonesia, 2014). 161

${ }^{59}$ B.J. Boland, Dogmatika Masa Kini,(Jakarta: Gunung Mulia, 2010). 127

${ }^{60}$ Christopph Barth, Dkk, Teologi Perjanjian Lama 1, (Jakarta: Gunung Mulia, 2008). 350

${ }^{61}$ Andrew Brake, Spiritual Formatian, (Bandung: Kalam Hidup, 2014). 179
} 
bukunya bahwa orang yang menyadari ketidak berdayaannya akan berdoa dengan sungguh-sungguh dan bersandar kepada Allah. Dengan demikian ia di kuatkan dan ia mampuh tetap berdiri teguh. ${ }^{62}$

Sama halnya yang telah dialami oleh Rasul Paulus. Caram kembali mengatakan dalam bukunya bahwa Paulus tetap setia waktu ia berada dalam kesusahan sama seperti waktu ia berada dalam keadaan baik. Tidak ada kondisi jatuh bangun dalam kehidupan Rasul Paulus. Ia telah mendapatkan Visi ilahi dan ini membuat ia hidup secara berbeda. Suatu visi yang baru mengubah cara berfikir dan cara hidup kita. ${ }^{63}$

Dari pemaparan di atas maka penulis menyimpulkan bahwa kesetiaan yang dimaksud melalui penjelasan diatas adalah kesetiaan umat kepada Allah melalui setiap persekutuan dengan umat percaya untuk memiliki hidup yang terus mencari Tuhan dan bersandar atas setiap kehendak Tuhan. Dalam hidup beriman pun harus dapat dinyatakan dengan hidup yang berkomitmen dalam hati untuk terus rindu mencari Tuhan dan bersandar terus dengan setiap kehendak Tuhan.

Ketaatan adalah buah dari iman setiap orang yang percaya kepada Tuhan. Iman tanpa ada ketaatan kepada perintah Tuhan tidak berguna. Iman timbul dari pendengaran dan pendengaran oleh Firman Tuhan, (Roma 10:17). Alkitab telah memberikan contoh bagi setiap orang percaya seorang bapak yang beriman dan memilki ketaatan yaitu Abraham. Abraham merupakan bapak dari segala iman Kristen yang telah memberikan contoh bagi orang percaya. John Perkins menjelaskan bahwa:

Tetapi Abraham menjadi bapa iman kita sebab walaupun dia hidup dalam zaman penyembahan berhala yang orang-orangnya percaya pada banyak dewa, ia percaya pada penyataan Allah kepadanya bahwa hanya ada satu Allah di surga. Dari berjalan keluar karena taat pada apa yang Tuhan suruh ia kerjakan-yaitu meninggalkan semua dewa lain dan kaum keluarganya, dan pergi ke negeri yang baru. dan ia pergi dengan taat, Imanya-kepercayaannya Allah dan perbuatanya berdasarkan kepercayaan itu menjadikannya bapa iman kita. ${ }^{64}$

Jadi ketaatan merupakan bentuk kerendahan hati setiap orang percaya kepada Allah, jadi iman yang benar selalu terarah kepada Kristus dan percaya Allah yang menopang seluruh hidup orang percaya. Ketaatan juga dapat dilihat dari setiap kehidupan sehari-hari apakah setaip orang percaya hidup dalam kebenaran Firman Tuhan. Iman

\footnotetext{
${ }^{62}$ Paul G. Cara, Kekristenan Sejati, (Jakarta: Voice, 2004). 105

${ }^{63}$ Ibid,...7

${ }^{64}$ John Perkins, Pola Hidup Kristen, (Malang: Gandum Mas, 1989). 285
} 
adalah ketaatan terhadap perintah Tuhan, dan keatatan menimbulkan kerendahan hati kepada Tuhan.

\section{Iman Disertai Dengan Perbuatan}

Manusia tidak hanya berfikir dan menilai, dia juga memiliki proyek-proyek yang ia kerjakan. Pemikiran dan penilainnya turut mempengaruhi proyeknya, menentukan sarana yang dipergunakannya,dan juga tindakannya. Sebaliknya juga proyeknya membentuk pemikirannya dan mempengaruhi kepercayaanya. ${ }^{65}$ Abineno menegaskan dalam bukunya bahwa Iman Kristen adalah pemberian atau anugerah Allah. Pemberian atau anugerah Allah tidak membuat manusia menjadi passif. Malahan sebaliknya: dalam iman, yang Allah berikan kepadanya, manusia aktif. sebab beriman artinya: mengulurkan tangan kepada Allah untuk menyambut tanganNya, yang terlebih dahulu di ulurkanNya (sebgai anugerah) kepada manusia. ${ }^{66}$ Oleh karena imanlah setiap orang percaya dibenarkan dan oleh karena imanlah manusia tidak lepas dari hukuman dosa.

Menurut Rom.8:33,34 kata "membenarkan" menjadi lawan kata "menghukum" jikalau demikian, maka yang disebut "membenarkan" adalah tindakan Allah sebagai Hakim, yang setelah menghakimi manusia menjatuhkan putusan, bahwa orang yang dihakiki tadi “benar' artinya “tidak bersalah”. Dan oleh karenanya tidak dihukum. ${ }^{67}$

Kata pembenaran adalah kata yang dipakai dibidang kehakiman. Allah membenarkan manusia, artinya menganggap manusia tidak bersalah, adalah sama dengan Allah mengampuni dosa manusia atau Allah mendamaikan manusia dengan diriNya sendiri atau Allah menjadikan manusia menjadi anak-anakNya. Menurut Roma.3:21,23 agar manusia dapat dibenarkan di dalam penghakiman Allah, ia harus memiliki "kebanaran Allah" karena iman dalam Yesus Kristus. ${ }^{68}$ Jadi penulis menyimpulkan bahwa manusia haruslah memiliki pembenaran yaitu "kebenaran Allah" sebab kebenaran di dalam Kristus memberi jaminan hidup bagi setiap orang yang percaya kepada-Nya. Menurut Prime mengatakan dalam bukunya pembenaran ialah:

Kebenaran adalah kebenaran yang yang kelak pada akhir Zaman akan menjadikan orang dappat bertahan dihadapan meja penghakiman Tuhan Allah. Kebenaran berpusat iman kita kepada Kristus atas dasar

${ }^{65}$ Arthur F. Holmes, Segala Kebenaran adalah Kebenaran Allah.(Surabaya: Momentum, 2005). 196

${ }^{66}$ J.L. Ch. Abineno, Pokok-pokok penting dari Iman Kristen, (Jakarta: Gunung Mulia, 2008). 3

${ }^{67}$ Harun Hadiwijono, Iman Kristen, (Jakarta: Gunung Mulia, 2005). 407

${ }^{68}$ R. Soedarmo, Ikhtisar Dogmatika, (Jakarta: Gunung Mulia, 1993). 195 
kematian dan kebangkitan Kristus. Dengan kejadian itu Kristus menjadi alat pendamai bagi Allah antara manusia dengan Allah. ${ }^{69}$

Jadi, penulis menyimpulkan bahwa iman adalah suatu pembenaran dalam setiap hidup orang percaya, di mana iman menjamin bahwa jalan hidup adalah Kristus. Dengan satu catatan bahwa Allah sumber kebenaran dan sumber kehidupan bagi setiap orang percaya yang mengandalkan Dia.

\section{APLIKASI MAKNA IMAN BERDASARKAN IBRANI 11:1-3}

Berdasarkan kajian eksegetikal dan tinjauan teologis tentang makna iman dalam

Ibrani 11:1-3 maka ada beberapa aplikasi penting untuk diterapkan oleh orang percaya, yaitu: menyerahkan diri secara total kepada Allah, memiliki ketaatan dan kesetiaan kepada Allah dan memiliki iman yang disertai dengan perbuatan.

\section{Menyerahkan Diri Secara Total Kepada Allah}

Tidak semua orang memiliki kesadaran untuk menyerahkan diri secara totalitas kepada Tuhan, ada kalahnya manusia hanya sebagai runtinitas saja untuk percaya bahwa Allah adalah Maha kuasa. Semakin banyak manusia semakin meragukan hubungan dengan Tuhan. Pada zaman moderen ini begitu sulit setiap orang percaya menyerahkan dirinya dengan sepenuh hati, dan dengan totalitas kepada Allah, lebih cederung adalah mengikuti keinginan duniawi dan keinginan diri sendiri. Dalam hal ini bukan berarti setiap orang percaya tidak bisa menyerahkan totalitas dirinya kepada Tuhan, akan tetapi penyerahan diri adalah merupakan kesimpulan atau keputusan yang ada dalam diri seseorang dalam hidupnya.

Menurut kitab Roma 12:1 penyerahan diri secara total ialah mempersembahkan hidup dengan sepenuhnya dihadapan Tuhan, Sebagai orang percaya haruslah memiliki iman yang berkualitas yang tidak mudah kendor terhadap masalah dan berbagai pencobaan tetap hati hanya tertujuk kepada Tuhan sebagai Juruselamat manusia. Selanjutnya penyerahan diri ialah bukan hanya sekdar menyerahkan diri saja dihadapan Tuhan, tetapi penyerahan diri disini ialah secara totalitas, segenap hati, segenap akal budi, pikiran, serta benar-benar mengabdi kepada Tuhan. Hal ini menunjukan kesungguhan hati dan ketekuna hati kepada Tuhan. Hal ini mustahil untuk dilakukan setiap orang percaya, sebab keinginan daging dan hawa nafsu dunia, dan pengaruh semakin besar sehingga setiap orang percaya sulit untuk menyerahkan diri secara totalitas kepada Tuhan. Dengan demikian bukan

69 Derek Prime, Tanya Jawab Tentang Iman Kristen, (Jakarta:Yayasan Komunikasi Bina Kasih/OMF, 2006). 81 
dalam arti setiap orang percaya tidak bisa melakukan, sebenarnya bisa asalkan setiap orang percaya mengambil komitmen dalam hatinya untuk tetap setia kepada Tuhan, dan menghandalkan Dia sebagai Tuhan dan juruselamat manusia. Hal ini membuktikan bahwa salah bukti iman adalah menyerahkan diri secara total kepada Tuhan. Dengan demikian ketika menyerahkan diri untuk dipimpin oleh Tuhan makan apapun yang terjadi tetap tegak dihadapan Tuhan, (2 Korintus 13:5).

Dalam Yohanes 14:12 berkata bahwa "Aku berkata kepadamu: sesungguhnya barangsiapa percaya kepada-Ku, ia akan melakukan juga pekerjaan-pekerjaan yang Aku lakukan, bahkan pekerjaan-pekerjaan yang lebih besar dari pada itu. Sebab Aku pergi kepada Bapa" artinya bahwa setiap yang percaya dan yang telah menyerahkan dirinya dipimpin oleh Tuhan, dengan kekuatan Tuhan orang percaya mampu melakukan perkaraperkara yang besar, (Lukas 10:16). Orang yang sudah menyerahkan diri secara total dihadapan Tuhan, berarti mampu mengendalikan diri dari pikiran-pikiran yang tinggi yang hanya menuruti keinginan duniawi, (Roma 12:3). Memang setiap orang percaya tidak memiliki masalah dalam iman, tetapi orang percaya memiliki masalah dalam pengetahuan, untuk itu marilah belajar bagimana pekerjaan iman dalam setiap orang percaya. Orang percaya harus mengakui bahwa iman yang dia peroleh adalah berasal dari Tuhan, (Filemon $1: 6)$.

Oleh sebab itu, tidak perlu meragukan kuasa Tuhan atas diri setiap orang percaya, sebab oleh kasih karunia Tuhanlah manusia diselamatkan dan diberikan kuasa untuk dapat mengendalikan diri dari keinginan duniawi, (2 Petrus 1:2-4). Salah satu bukti penyerahan diri secara Alkitab ialah Filipi 1:21 berkata bahwa "karena bagiku hidup adalah Kristus dan mati adalah keuntungan". Hal ini memberi pemahaman yang tepat bagi setiap orang percaya bahwa ketika menyerahkan diri secara total dihadapan Tuhan mati pun keuntungan baginya. Inilah salah satu bentuk sifat orang percaya yang sudah benar-benar menyerahkan diri kepada Tuhan dengan segenap hati, dan mau dipimpin oleh Tuhan.

\section{Memiliki Ketaatan dan Kesetiaan Kepada Allah}

Orang Kristen harus mengejar kesetiaan dalam mempertahankan iman kepada Tuhan apa pun yang terjadi. Kristen yang memiliki kesetiaan harus mampu menunjukkan iman yang kuat, yang berbobot, bukan iman yang kosong dan mati tetapi dapat diteladani. Kata 'setia' dalam bahasa Ibrani, berasal dari sebuah kata yang berarti 'sokong' atau tanggung'. Orang yang setia berarti orang yang dapat menyongkong, yang menanggung, yang kepada-Nya dapat bersandar tanpa merasa kuatir (Ul. 7:9;32:4; Yes. 49:7; 1 Kor. 1:9; 
10:13, 1 Tes. 5:24, 2 Tes. 3:3, 1 Yoh. 1:9). Dapat disimpulkan bahwa orang yang setia adalah seorang yang menyadari bahwa Allah setia sehingga ia mau untuk memperhatikan satu sama lain sebagai saudara dalam Tuhan. Kesetiaan ini juga terdalam di dalam Amsal 20:6,"tetapi, orang yang setia siapakah yang menemukannya" ayat ini memiliki arti, kesetiaan itu langkah di temukan, karena itu ketika orang percaya memiliki kesetiaan, maka ia akan memjadi telada bagi dunia yang dahaga akan kesetiaan.

Dapat di simpulkan bahwa tidak semua orang memiliki kesetiaan itu, tetapi ketika orang percaya memiliki kesetiaan di hadapan Tuhan maka dari situlah orang percaya dapat menjadi teladan bagi dunia. Naftrik mengatakan bahwa kesetiaan Allah sang khalik adalah kesetiaan terhadap dunia dan manusia yang berdosa. Salah satu mengapa orang percaya kurang kesetiaan ialah karena orang percaya mudag terpengaruh terhadap pengajarah sesat, karena orang percaya terlalu mementingkan diri sendiri, dan karena orang percaya kurang percaya diri sehingga ketika diperhadapkan masalah kesetian dan ketaatan tersebut hilang. Akibat dari ketidak setiaan adalah banyak orang percaya menjadi murtad, dan berpaling dari imannya kepada Yesus. Dalam zaman ke-zanman sulit untuk menemukan orang yang setia kepada imannya, sulit untuk menemukan orang yang taat, kepada imanya bahkan ada yang meragukan imanya, kepercayaan kepada Tuhan.

Hal ini terjadi karena pola hidup manusia yang semakin hari semakin berubah, bahkan perkembangan zaman yang semakin mengubahkan pola kehidupan orang percaya yang mengutamakan ialah pengetahuan, intelektual, kecedasan, kebebasan, sehingga tidak ada namanya takut akan Tuhan yang ada semuanya mengandalkan kekuatan sendiri. Dalam Alkitab berkata, “ iman adalah dasar dari segala sersuatu yang kita harapkan dan bukti dari segala sesuatu yang tidak kita lihat" (Ibrani 11:1). Iman dalam arti yang sebenarnya adalah percaya dan menaati Firman Allah. Hal ini telah memberi contoh Alkitab tentang iman Abraham yang telah menjadi bapa iman bagi setiap umat manusia. Iman Abraham ialah ketaatanya kepada Allah dan kesetiaannya kepada Firman Allah, Abraham tidak mengabaikan perkataan atau perintah Allah dia terus setia dan taat sampai dia mengakhiri hidupnya.

Seseorang percaya mendapat iman dari Firman Allah. "jadi iman timbul dari pendengaran dan pendegaran oleh Firman Kristus" (Roma 10:17). Dalam suratnya kepada orang Roma, paulus menunjukkankepada orang percaya bahwa dunia berada dalam kegelapan kafir, tetapi ia "mempunyai keyakinan yang kokoh dalam injil, karena injil adalah kekuatan Allah yang menyelamatkan setiap orang yang percaya" (Roma 1:16). Injil 
Kristuslah yang merupakan dasar iman orang percaya. Itulah sebabnya orang harus mendengar Firman Tuhan, setia kepada Firman Tuhan, dan taat terhadap perintah Allah. Ketaatan orang percaya merupakan bentuk kerendahan diri dihadapan Tuhan, sehingga melalui ketaatan orang percaya tidak tinggi hati, tidak serakah, tetapi memiliki hati yang lemah lembut, dan ramah kepada sesamanya. Iman yang sejati ialah merupakan misteri dalam arti bahwa iman itu diberikan Allah bagi setiap orang yang percaya kepada-Nya. Iman sejati bukan dimulai dari dirinya sendiri, melainkan dimulai dari Allah, (Matius 16:13-17).

\section{Memiliki Iman Yang Disertai Dengan Perbuatan}

Yang dimaksud dengan perbuatan adalah kelakuan atau tindakan seseorang yang mengahasilkan sifat positif maupun negatif. Dalam hal ini memberi suatu pengajaran bagi setiap orangt percaya bahwa iman bukan hanya sekedar percaya, berkomitmen, ketaatan, kesetiaan, atau menyerahkan diri secara total kepada Tuhan. Akan tetapi iman adalah disertai dengan perbuatan, tindakan, dan kelakuan yang dapat dipercaya itulah iman yang sesungguhnya dihadapan Tuhan. Dalam Yakobus 2:17 berkata bahwa "Demikian juga halnya dengan iman: jika iman itu tidak disertai perbuatan, maka iman itu pada hakekatnya adalah mati." Artinya bahwa tindakan sangat penting bagi setiap orang yang percaya, sebab ketika tidak ada tindakan iman tidak berfungsi akibatnya kendor dan mati, dengan kata lain tidak ada gunanya.

Hendaklah setiap orang percaya memiliki iman yang disertai dengan perbuatan, karena melalui tindakan orang percayalah bahwa seseorang mempunyai iman yang sejati atau sebaliknya iman yang ada dalam diri orang percaya adalah iman diragukan. Perbuatan disini adalah perbuatan yang bersifat rohani, dan bersifat kekal. Bukan sebaliknya perbuatan adalah buruk. Hal ini memberikan dua pengertian bagi setiap orang percaya yang memang saling bertentangan dalam kehidupan orang percaya. Akan tetapi pilihan tersebut tergantung pada diri setiap orang percaya memiliki perbuatan baik atau perbuatan buruk. Tidak tertutup ke mungkinan bahwa masih banyka orang-orang percaya atau jemaat Tuhan yang masil memilih perbuatan buru. Contohnya ialah orang-orang percaya sering memilih kehendak hati, sering menuruti keinginan diri sendiri, dan selalu mengutamakan kesenangan duniawi dari pada dekat dengan Tuhan. Selanjutnya sering orang percaya tidak ada lagi rasa takut akan Tuhan dalam setiap rencanan tidak lagi melibatkan Tuhan, dan sering meragukan akan janji-janji Tuhan. Dengan demikiam sebagai orang percaya 
memberi suatu pemahaman yang paling dalam bahwa perbuatan haruslah seiring dengan iman yang teguh dihadapan Tuhan.

Sebaliknya sisi positifnya ialah orang yang sudah mengenal dan memahami kebenaran dan sudah tahu kebenaran, maka setiap tindakannya adalah menjadi berkat bagi sesamanya. Sebagai orang percaya haruslah memiliki hati yang mengasihi, memiliki kelamah-lembutan, dan sebagai orang percaya haruslah memiliki yang namanya integritas dalam setiap langkah kehidupanya. Iman kristen yang benar harus terlihat dalam perbuatan yang benar perbuatan kebenaran, perbuatan keadilan, perbuatan kemurahan. Jika iman tidak menghasilkan perbuatan yang benar, iman itu mati. Dan perbuatan saja, tanpa iman yang menunjannya, adalah mati. Dengan demikian iman tanpa perbuatan, iman tanpa tindakan kasih dan kemurahan, adalah samasekali bukan iman. Oleh sebab itu, hendaknyaa satiap orang percaya memiliki iman yang disertai dengan perbuatan, bukan iman yang hanya saja mengakui saya adalah orang percaya, tetapi tindakan dan perbuatan tidak ada sama sekali tidak berguna hakikatnya mati.

\section{PENUTUP}

Surat Ibrani 11:1-3, penulis surat Ibrani ini berusaha untuk menguatkan iman orang-orang percaya yang sudah mulai kendor imanya akibat pengaruh pengajaranpengajaran sesat yang sudah mulai menyebar di tengah-tengah orang percaya. Surat Ibrani ini terutama ditulis kepada orang-orang kristen Yahudi yang sedang mengalami penganiayaan dan keputusasaan. Penulis berusaha untuk memperkuat iman mereka kepada Kristus dengan menjelaskan secara teliti keunggulan dan ketegasan penyataan Allah dan penebusan di dalam Yesus Kristus. Hal ini menunjukkan bahwa penyediaan penebusan dibawah perjanjian yang lama sudah digenapi dan tidak terpakai lagi karena Yesus telah datang dan menetapkan suatu perjanjian yang baru oleh kematian-Nya yang mengerjakan perdamaian. Hal ini penulis menantang para pembaca yang pertama ialah untuk tetap mempertahankan pengakuan mereka terhadap Kristus hingga pada kesudahannya, kedua untuk maju terus menuju kedewasaan rohani, dan ketiga untuk tidak kembali kepada kehidupan dibawah hukuman dengan cara meninggalkan kepercayaan kepada Yesus Kristus.

Iman adalah dasar dari segala sesuatu bagi setiap orang percaya, dasar disini ialah pondasi atau ke-utamaan atau sering disebut akar. Jadi iman adalah akar atau pondasi serta ke-utamaan setiap orang yang percaya kepada Tuhan Yesus Kristus. Selanjutnya iman 
adalah dasar pengharapan bagi setiap orang yang percaya kepada Kristus. Pengharapan disini ialah, hasil atau buah juga disebut hadiah. Jadi setiap orang pecaya bahwa haruslah memiliki suatu pengharapan yang pasti kepada Tuhan dengan menantikan hadiah keselamatan, melalui buah iman yang telah dinyatakan bagi setiap orang yang percaya.

Selanjutnya bahwa iman juga adalah sering diartikan sebagai bukti bagi setiap orang percaya. Bukti disini ialah bersaksi, rela berkorban, dan rela menanggung derita inilah bukti iman menurut penulis. Jadi artinya bahwa orang percaya iman haruslah disertai dengan bukti dalam setiap kehidupannya, dalam perbuatannya, dalam tindakannya dalam sehari-hari. Iman juga memberi pengertian yang dalam yaitu sebagai seorang buta. Artinya bahwa sekalipun tidak melihat tetapi tujuan hidup setiap orang percaya yaitu tertuju kepada Tuhan. Hal sangatlah penting iman dalam setiap kehidupan orang percaya milikilah iman yang berkualitas seperti seorang buta, sekalipun tidak melihat namun kehidupanya terarah pada satu tujuan yaitu kehidupan yang kekal.

Hal ini telah nyata dalam kehidupan setiap orang percaya bahwa iman merupakah hal yang utama dalam hidup ini, tanpa iman, tanpa kepercayaan kepada Tuhan, pada hakekatnya adalah mati, atau tidak ada gunanya, (Yakobus 2:17). Dengan demikian iman sangatlah penting bagi setiap kehidupan orang percaya, sebab memalaui iman ada dua pilihan yaitu beriman kepada allah-allah lain atau sebaliknya percaya kepada Tuhan Yesus sebagai Tuhan dan juruselamat umat manusia yang telah menebus tiap-tiap orang percaya terhadap dosa.

\section{DAFTAR PUSTAKA}

Adiwijaya, Paulus. (2004). Rick Warren the Purpose Driven Life, Malang: Gandung Mas. Barth, Christoph, Dkk. (2008). Teologi Perjanjian Lama 1, Jakarta: Gunung Mulia. Benyamin Hakh, Samuel. (2010). Perjanjian Baru, Bandung: Bina Media Infomasi. Brake, Andrew. (2014). Spiritual Formatian, Bandung: Kalam Hidup. C. Tenney, Merill. (1997). Survei Perjanjian Baru, Malang: Gandum Mas. C. Van Niftrik, G. (2015). Dogmatika Masa Kini, Jakarta: Gunung Mulia. Dausey, Gary. (1989). Pola Hidup Kristen, Bandung: Yayasan Kalam Hidup. Deissmenn, A. (1929). The New Testament in The Light of Modern Research. Drane, John. (2011). Memahami Perjanjian Baru, Jakarta: BPK. Gunung Mulia. E. Duyverman. M., (2011). Pembimbing ke Dalam Perjanjian Baru, Jakarta: Gunung Mulia. 
F. Holmes, Arthur. (2005). Segala Kebenaran Adalah Kebenaran Allah, Surabaya: Momentum

Fance, Eddy. (2005). Mengenal Dan Dikenal Allah, Jakarta: Yayasan Sinar Nusantara.

Fernando, Ajith. (1989). Pola Hidup, Bandung: Kalam Hidup.

Friberg, Analytical Greed exicon, Bibleworks 21981

G. Paul. (2004). Cara, KeKristenan Sejati, Jakarta: Voice.

Guthrie, Donald. (2010). Pengatar Perjanjian Baru Volume 3, Surabaya: Momentum.

Hadiwijono, Harun. (2005). Iman Kristen, Jakarta: Gunung Mulia.

Hagin, Kenneth. (1979). How to Write Your Own Ticket With God, Faith Library, Tulsa.

Halversion, Richard. (1989). Pola Hidup Kristen, Malang: Gandum Mas

Henry, Matthew. (2016). Tafsiran Surat Ibrani, Yakobus, 1\&2 Petrus, 1-3 Yohanes, Yudas, Kitab Wahyu, Surabaya: Momentum.

Henry, Matthew. (2016). Tafsiran Surat Ibrani, Yakobus, $1 \& 2$ Petrus, 1-3 Yohanes, Yudas, Kitab Wahyu, Surabaya: Momentum.

Herlianto. (1996). Toronto Blessing, Bandung: YABINA.

Hoekema, A. (2004). Alkitab dan Akhir Zaman, Surabaya: Momentum.

J. Bailey, Brian. (2005). Pilar-Pilar Iman, Jakarta: Zion Christian Publications.

J. Boland, B. (2010). Dogmatika Masa Kini, Jakarta: Gunung Mulia.

L. Ch. Abineno, J. (2008). Pokok-pokok penting dari Iman Kristen, Jakarta: Gunung Mulia.

Marty, Marthin. (1989). Pola Hidup Kristen, Surabaya: Yakin.

Motyer, Alec. (2003). Tafsiran Alkitab Masa Kini 3, Jakarta: Yayasan Bima Kasih.

Oke, Janette. (1989). Pola Hidup Kristen, Malang: Gandum MAS.

Perkins, John. (1989). Pola Hidup Kristen, Malang: Gandum Mas.

Prime, Derek. (2006). Tanya Jawab Tentang Iman Kristen, Jakarta:Yayasan Komunikasi Bina Kasih.

Prime, Derek. (----). Tanya Jawab tentang Iman Kristen, Jakarta: Yayasan Komunikasi Bina Kasih/OMF.

R.F Browning, W. (2011). Kamus Alkitab, Jakarta: Gunung Mulia.

Rey, Hendra. (2014). Menata Hidup Serupa Kristus, Bandung: PT. Visi Anugerah Indonesia.

Sabdono, Erastus. (2017). Pelayanan Yang Sesungguhnya, Jakarta: Rehobot Literatur. 
Simanjuntak, A. (2003). Tafsiran Alkitab Masa Kini 3 Matius-Wahyu, Jakarta: Yayasan Komunikasi Bina Kasih/OMF.

Soedarmo,R. (....). Ikhtisar Dogmatika, Jakarta: Gunung Mulia.

Subandrijo, Bambang. (2010). Menyikap Pesan-Pesan Perajanjian Baru, Bandung: Bina Media Informasi.

Sugiri SJ, L. (2006). Gerakan Kharismatik apakah itu?, Jakarta: BPK Gunung Mulia.

Sugono, Dendy. (....). Kamus Besar Bahasa Indonesia Pusat Bahasa, Jakarta: Gramedia Pustaka Utama.

Sujoko, Albertus. (2009). Identitas Yesus dan misteri Manusia, Yogyakarta: KANISIUS.

Swetnam. (1974). "From and Content in Hebrews 7-13," Biblica.

Vanhoye, A. (1976). La Structure Litteraire de I'Empire aux Hebreux.

Wei Fong, Yep. (2015). Handbook to the Bible "Pedoman Lengkap Pendalaman Alkitab" Bandung: Kalam Hidup.

Wesley Brill, J. (1991). Dasar Yang Teguh, Bandung: Kantor Kalam Hidup. (2004). Tafsiran Surat Ibrani, Bandung: Kalam Hidup.

Wommack, Andrew. (2010). Roh, Jiwa, Tubuh, Light Publishing. 